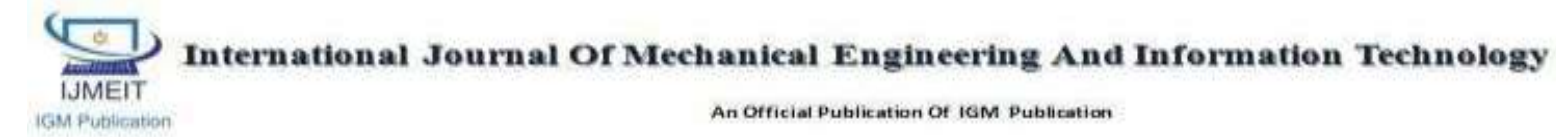

Index Copernicus Value-63.45

\title{
Modelling and CFD analysis of Shell \& Tube Heat Exchanger
}

\author{
Authors \\ Keshav Raj Khatkar', R. M. Sarviya ${ }^{2}$ \\ ${ }^{1}$ PG Student, Department of Mechanical Engineering, Maulana Azad National Institute of Technology, \\ Bhopal, \\ ${ }^{2}$ Professor, Department of Mechanical Engineering, Maulana Azad National Institute of Technology, \\ Bhopal, \\ Email Id: Rajkeshav7@gmail.com
}

\begin{abstract}
A heat exchanger is a device that is used to transfer thermal energy (enthalpy) between two or more fluids, at different temperatures and in thermal contact. In this problem of heat transfer different constructional parameters are changed for getting the performance review under different condition. The tube diameter, tube length, shell types etc. are all standardized and are available only in certain sizes and geometry. Since several discrete combinations of the design configurations are possible, the designer needs an efficient strategy to quickly locate the design configuration having the minimum heat exchanger cost. In this problem, the tube metallurgy is being changed and the results are obtained. In current work, the tube metallurgy is the parameters considering change and effect on the heat exchanger. In this work, for the Design of shell and tube heat exchangers is done on CREO by taking the outer diameter of shell as $135 \mathrm{~mm}$, length of the shell is $800 \mathrm{~mm}$ and Outer diameter of tube is $15 \mathrm{~mm}$, length of Tube is $800 \mathrm{~mm}$ and Shell material as Aluminium, Brass, Copper and Steel 1008. By using ANSYS 16.1 software, the thermal analysis of Shell and Tube heat exchangers is carried out by varying the Tube materials keeping Inlet of Hot fluid as $60^{\circ} \mathrm{C}$ while the inlet of cold fluid is kept as $30^{\circ} \mathrm{C}$. Comparison is made between the ANSYS results. With the help of the available numerical results, the design of Shell and Tube heat exchangers can be altered for better efficiency.
\end{abstract}

Keywords- Shell and Tube heat exchangers, ANSYS, CREO.

\section{INTRODUCTION}

Heat exchanger is a steady flow adiabatic device (Open system) in which two flowing fluids transfer or exchange heat between them without losing or gaining any heat from the atmosphere. Heat exchanger transfers thermal energy from a hightemperature fluid to a low- temperature fluid with both fluids moving through the device. Heat exchangers are used to exchange thermal energy between a solid surface and a fluid, between two or more fluids, between solid particulates and a fluid at different temperatures in thermal contact with each other. A Steady State Thermal analysis is an analysis to find the Temperature, Heat Flux and Directional Heat Flux in any complex structure or components by applying boundary conditions that do not bring any significant effect. Response condition and steady loading are assumed in analysis. The Thermal and applying load response are assumed to be very slowly with respect to time. A static structure analysis is performed using different software like ANSYS, Samcef, or ABAQUS solver. The thermal analysis is performed on ANSYS 16.1 software.

\section{LITERATURE REVIEW}

Various research papers related to the thermal analysis of heat exchanger using CFD simulation have been reviewed in this chapter. The brief description of these papers is presented in this chapter. 
Ender Ozden et al [2010] investigated the shell diameter, baffle spacing, tube diameter and pressure drop by numerical modelling of heat exchanger. The temperature and flow fields inside the shell are obtained by CFD simulation. A set of CFD simulation is performed for a single shell and tube pass heat exchanger for different number of baffles and turbulent flow. All the parameters including heat transfer coefficient, pressure drop and outlet temperature are compared for different-different values. Effect of baffle spacing to shell diameter ratio also investigated by changing flow rate.

Durgesh Bhatt et al [2012] studied the problem of heat transfer involving the conditions where different parameters are changed for getting the performance review under different conditions. An excel program sheet has been developed for the ease of calculation and obtaining result after changing different parameters. The tube diameter, shell types, tube length etc. are all standardized and are available only in certain sizes and geometry. Design of a shell-and-tube heat exchanger usually involves a trial and error procedure. In this problem, the baffle spacing and tube metallurgy are being changed and the results are obtained. Higher the thermal conductivity of the tube metallurgy higher the heat transfer rate will be achieved. When the baffle spacing is less, the shell side passes will be more and higher will be the heat transfer but at the cost of the pressure drop. So, while optimization it must be taken care that the advantage in one of the output parameter can affect the other parameters, which can lead to increase in initial or operating cost.

Amitesh Paul et al [2012] investigated that tubular heat exchangers are generally built of circular tubes, although elliptical, rectangular, round or flat twisted tubes have also been used in some applications. There is considerable flexibility in design because the core geometry can be varied easily by changing the tube diameter, length, and arrangement. Tubular type of heat exchangers can be designed for high pressures relative to ambient and high-pressure differences between the different fluids. These are used for gas-to liquid and gas to gas heat transfer applications primarily when the operating temperature and pressure is very high or fouling is a severe problem. It is found that copper material gives the better heat transfer rates than the aluminium material.

Hetal Kotwal et al [2013] studied the thermal analysis of shell and tube heat exchanger using different turbulence models available in CFD tools i.e. Standard k- $\varepsilon$ model, k- $\varepsilon$ RNG model, Realizable k- $\varepsilon, \mathrm{k}-\omega$ and RSM model in conjunction with velocity pressure coupling scheme. The quality of the solution has proved that CFD is effective to predict the behaviour and performance of heat exchanger. CFD provide alternative to cost effectiveness speedy solution to heat exchanger design and optimization.

Triloki Nath Mishra [2013] studied about the helical coil heat exchanger. It has a widespread range of application in the industries than the straight type heat exchanger because of its greater heat transfer area, higher mass transfer coefficient and higher heat transfer abilities. Modelling of heat exchanger was done on CATIA V5 and CFD analysis on ANSYS. Copper was used as the constructional material for both the inner and outer parts. ANSYS 13.0 was used to plot pressure contour, velocity contour and temperature contour. Result after analysis shows that temperature, pressure velocity contour in the heat exchanger were like literature data and It is also visible from the results that Nusselt Number depends on curvature ratio. It increases with increase in curvature ratio. In addition, the value of $\mathrm{Nu}$ no. was found to increase with increase in mass flow rate (i.e. inlet velocity), with increases in $\mathrm{D} / \mathrm{d}$ ratio (inverse of curvature ratio) the Nusselt number will decreases; for a value of Reynolds number.

Gajanan P Nagre et al [2014] studied about the factors affecting the performance of shell and tube heat exchanger with counter flow arrangements. Thermal analysis is carried out considering various parameters such as baffle inclination, baffle spacing, flow rates of hot and cold fluids, tube length, tube diameter, shell diameter etc. by using CFD simulation. It was designed by theoretical methods (Bell Delaware and Kern methods) and after that CFD simulation is used for its thermal analysis. 
Then it is compared with the theoretical system to find out the factors affecting the performance of the shell and tube heat exchanger. It was found that dimensions can be altered to enhance the performance of the system.

B. Jayachandriah et al [2014] studied and found that Tubular Heat exchangers can be designed for high pressures relative to environment and high-pressure differences between the fluids. An attempt is made in this paper is for the Design of shell and tube heat exchangers by modelling in CATIA V5 by taking the Inner Diameter of shell, length of the shell and Outer diameter of tube length of Tube and Shell material as Steel 1008, Tube material as Copper and Brass. By using modelling procedure assembly of Shell and Tube with water as medium was done. By using ANSYS software, the thermal analysis of Shell and Tube heat exchangers is carried out by varying the Tube materials. Analysis has been done by changing materials of the tube and it was found that copper material gives better heat transfer rates in comparison to the brass material. Rate of heat transfer can be improved by changing the geometry, the pitch lay out, temperature of tubes, changing the materials of tubes.

Vindhya Vasiny Prasad Dubey et al [2014] investigated the basic model of counter flow shell and tube type heat exchanger having water as interacting medium on both the sides. In this paper, a shell and tube heat exchanger was designed to cool water from $55^{\circ} \mathrm{C}$ to $45^{\circ} \mathrm{C}$ by water at room temperature. It was designed using Kern's method to obtain various dimensions such as shell, tubes, baffles etc. A computer model using ANSYS 14.0 has been developed by using the derived dimensions of heat exchanger. The steady state thermal analysis of shell and tube heat exchanger in ANSYS has been processed by applying different thermal loads on different components having different faces and edges. The heat transfer capabilities of several thermal materials have been compared by assigning different materials to various parts such as tubes, baffles, and shell. It was found that when copper was used for whole parts then it transferred the maximum heat flux but it was very costly too. So, shell material is designed with the steel whereas baffles were designed with copper for maximum heat flux.

\section{PROBLEM IDENTIFICATION}

In the present work, the study of heat transfer capabilities of various thermal materials that are used for shells and tubes of shell and tube type heat exchanger is performed. The study of material properties becomes necessary when it is required to exchange a large amount of heat within a minimum stipulated time to meet out process and production standards as well as to secure the time economy. Also in the large installation, it is always desired that the material could handle the overload situations as and when demanded, hence a good conductor may be employed instead of moderate one, but cannot use moderate one where good heat transfer capabilities is demanded. Under these circumstances it is inevitable to ensure the good heat transfer capabilities of the materials required for the designing of heat exchanger. Therefore, four materials are considered viz. aluminium, brass, copper and steel 1008. Comparison in their heat transfer capabilities under the above designed conditions and selecting the most suitable one. Design of shell and tube heat exchanger using CREO and thermal analysis to be done on the ANSYS 16.1.

This work is focused on the study of temperature variation and Heat distribution with respect to the various materials and their effects on properties of the above parameters inside the shell and tube heat exchanger.

\section{METHODOLOGY}

The 3D geometric modelling is required for thermal analysis of Shell \& Tube Heat exchanger. In present work, the geometry of Shell \& Tube heat exchanger is taken for analysis. The shell \& tube heat exchanger is consisting of many tubes surrounded by a shell. Baffles are provided to ensure the direction of flow in the right direction. In this modelling, geometry is designed in the CREO software whereas thermal analysis is done on the ANSYS 16.1. The computational model of a Shell and Tube Heat Exchanger (STHX) is shown in Fig 
4.1 and the geometry parameters are listed below. As can be seen from Fig, the simulated STHX has a shell consisting of tubes. The total number of tubes are 37. The inner side of the shell and everything in the shell contained in the domain bounds the whole computation domain. The inlet and outlet of the domain relate to the corresponding tubes. To simplify numerical simulation, some basic characteristics of the process following assumptions are made:

1. The shell side and tube side fluids are at constant thermal properties

2. The fluid flow and heat transfer processes are in steady state in one condition and transient in another condition

3. The natural convection induced by the fluid density variation is neglected

4. The temperature of the tube wall has been kept constant in the entire process

5. The heat exchanger is well insulated hence the heat loss to the environment is totally neglected.

Table 4.1 Geometry Parameters

$\begin{array}{ll}\text { No of tubes } & 37 \\ \text { Length of the tubes } & 800 \mathrm{~mm} \\ \text { Tube diameter } & 15 \mathrm{~mm} \\ \text { Clearance } & 7 \mathrm{~mm} \\ \text { Shell length } & 800 \mathrm{~mm} \\ \text { Shell diameter } & 135 \mathrm{~mm} \\ \text { Thickness } & 9 \mathrm{~mm}\end{array}$

Table 4.2 Thermal Properties

$\begin{array}{ll}\text { Aluminium: } & \\ \text { Thermal Conductivity } & 237.5 \mathrm{~W} / \mathrm{m}^{0} \mathrm{C} \\ \text { Density } & 2689 \mathrm{~kg} / \mathrm{m}^{3} \\ \text { Specific heat } & 951 \mathrm{~J} / \mathrm{kg}^{0} \mathrm{C} \\ \text { Brass: } & \\ \text { Thermal Conductivity } & 111 \mathrm{~W} / \mathrm{m}^{0} \mathrm{C} \\ \text { Density } & 8600 \mathrm{~kg} / \mathrm{m}^{3} \\ \text { Specific heat } & 162 \mathrm{~J} / \mathrm{kg}^{0} \mathrm{C} \\ \text { Copper: } & \\ \text { Thermal Conductivity } & 400 \mathrm{~W} / \mathrm{m}^{0} \mathrm{C} \\ \text { Density } & 8933 \mathrm{~kg} / \mathrm{m}^{3} \\ \text { Specific heat } & 385 \mathrm{~J} / \mathrm{kg}^{0} \mathrm{C} \\ \text { Steel 1008: } & \\ \text { Thermal Conductivity } & 45 \mathrm{~W} / \mathrm{m}^{0} \mathrm{C} \\ \text { Density } & 7872 \mathrm{~kg} / \mathrm{m}^{3} \\ \text { Specific heat } & 481 \mathrm{~J} / \mathrm{kg}^{0} \mathrm{C} \\ \text { Fresh water: } & \\ \text { Thermal Conductivity } & 0.604 \mathrm{~W} / \mathrm{m}^{0} \mathrm{C} \\ \text { Density } & 997.4 \mathrm{~kg} / \mathrm{m}^{3} \\ \text { Specific heat } & 4179 \mathrm{~J} / \mathrm{kg}^{0} \mathrm{C}\end{array}$

\section{Solid Modelling:}

Geometry of the shell and tube heat exchanger is done on the CREO software and then it is generated in the ANSYS Workbench tool for removing any type of error. There is many software to design shell and tube heat exchanger viz. CAD/CAM, PRO E, CATIA V5, CREO. Design modeler of ANSYS Workbench can also be used to create complex geometry. In this work geometry is created by the CREO software and thermal analysis of the shell and tube heat exchanger is done on the ANSYS 16.1 software. After the geometry creation, it is shown in the figure 4.1 in which the study has been carried out. Geometry of tubes has also been analysed by hiding the shell component of the heat exchanger.

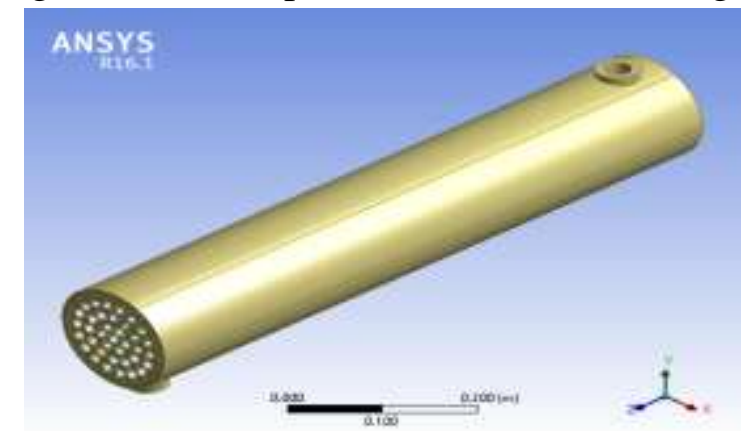

Figure 4.1: Shell and Tube Heat Exchanger

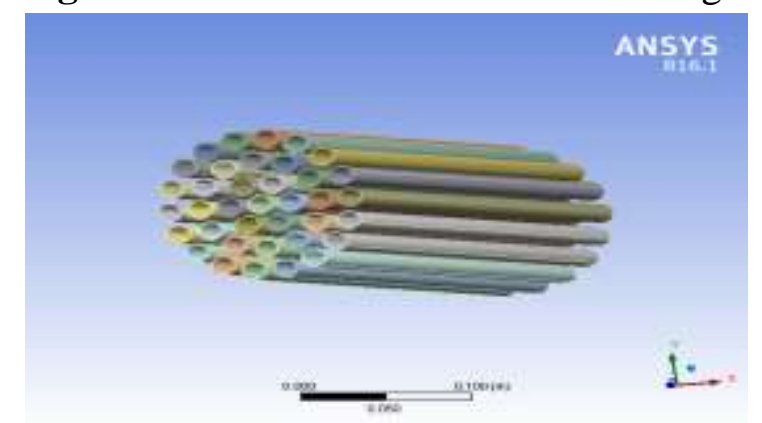

Figure 4.2: Tubes of STHE

\section{Meshing:}

Initially a relatively finer mesh is generated with 1.8 Million cells. This mesh contains cells (Tetra) having triangular faces at the boundaries. Care is taken to use structured cells (Tetrahedral) as much as possible, for this reason the geometry is divided into several parts for using automatic methods available in the ANSYS meshing client. It is meant to reduce numerical diffusion as much as possible by structuring the mesh in a well manner, particularly near the wall region. Later, for the mesh independent model, a fine mesh is generated with fine cells. For this fine mesh, the edges and regions 


\section{IJMEIT// Vol.05 Issue 07//July//Page No: 1663-1670//ISSN-2348-196x}

of elevated temperature and pressure gradients are finely meshed.

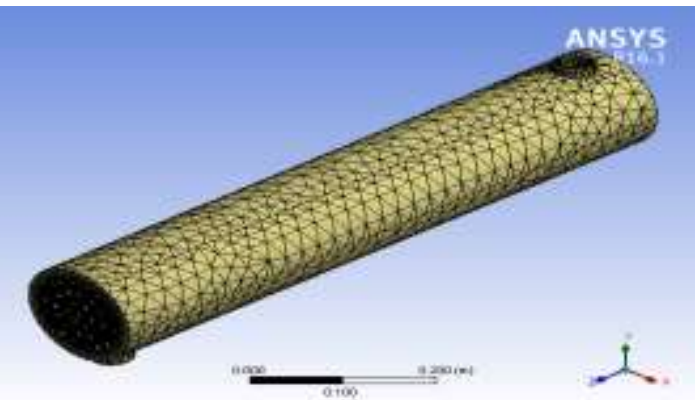

Figure 4.3: Meshing of STHE

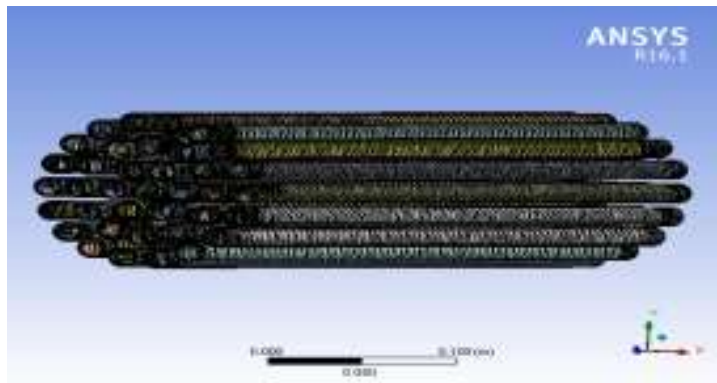

Figure 4.4: Meshing of tubes

\section{RESULTS \& DISCUSSIONS}

In the present study of shell and tube heat exchanger numerical simulations have been carried out for temperature $60^{\circ} \mathrm{C}$ at shell inlet and $30^{\circ} \mathrm{C}$ at tube inlet. At the outlet of the shell convection is taken as $3000 \mathrm{~W} / \mathrm{m}^{2}$ and temperature as $43^{\circ} \mathrm{C}$. At the outlet of the tube convection is taken as $3000 \mathrm{~W} / \mathrm{m} 2$ and temperature as $37^{\circ} \mathrm{C}$. In this work, steady state thermal analysis has been carried out at various conditions for proper comparison between the analysis.

\section{Aluminium in Parallel flow}

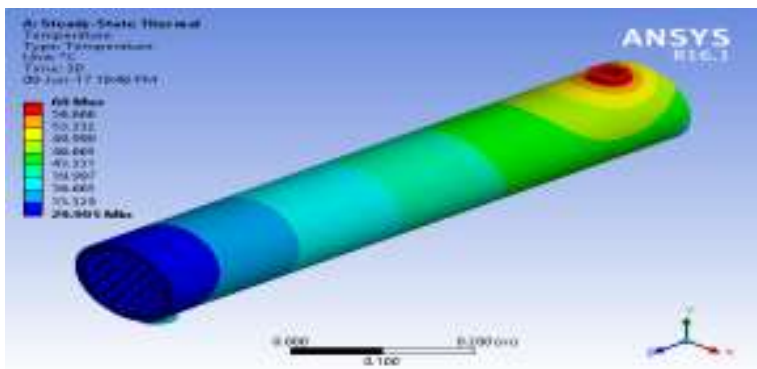

Figure 5.1: Temperature distribution in Aluminium

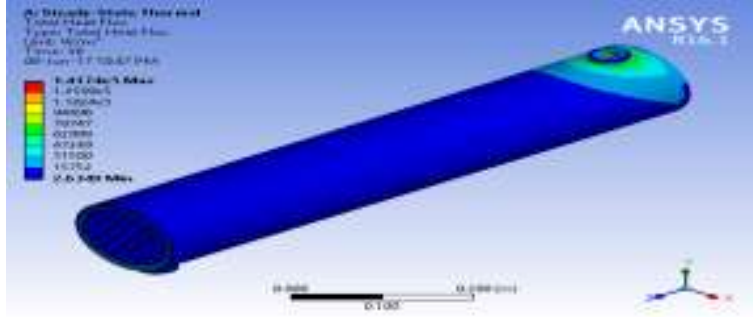

Figure 5.2: Heat distribution in Aluminium
Figure 5.1 and 5.2 shows the temperature variation and heat distribution in Aluminium in Parallel flow arrangement. The maximum and minimum values of the heat flux came out to be $2.3227 \times 10^{5}$ and $0.023067 \mathrm{~W} / \mathrm{m}^{2}$.

\section{Aluminium in Counter flow}

Figure 5.3 and 5.4 shows the temperature variation and heat distribution in Aluminium in Counter flow arrangement. The maximum and minimum values of the heat flux came out to be $3.9234 \times 10^{5}$ and $0.025584 \mathrm{~W} / \mathrm{m}^{2}$.

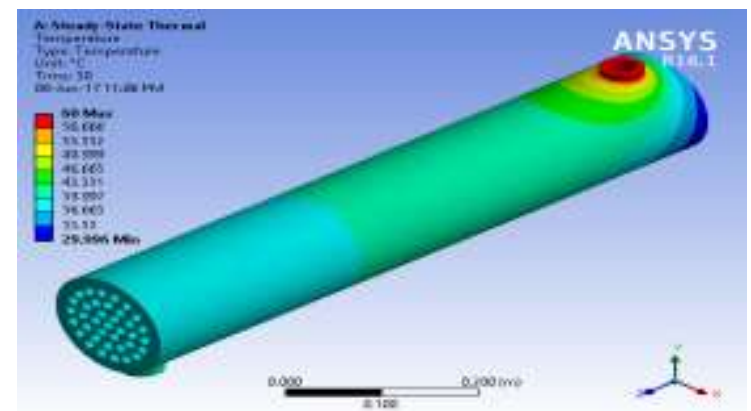

Figure 5.3: Temperature distribution in Aluminium

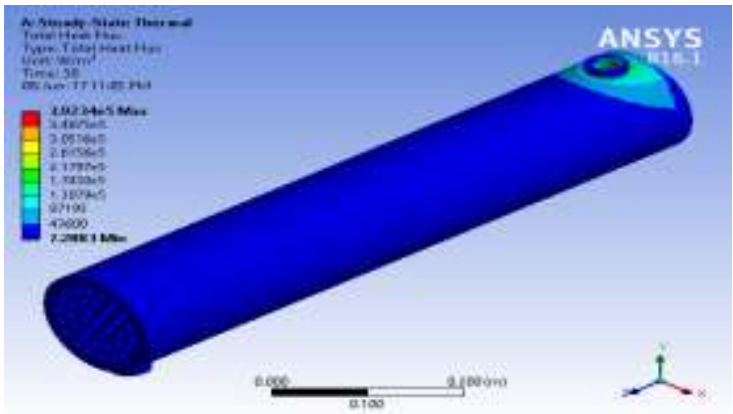

Figure 5.4: Heat distribution in Aluminium Brass in Parallel flow

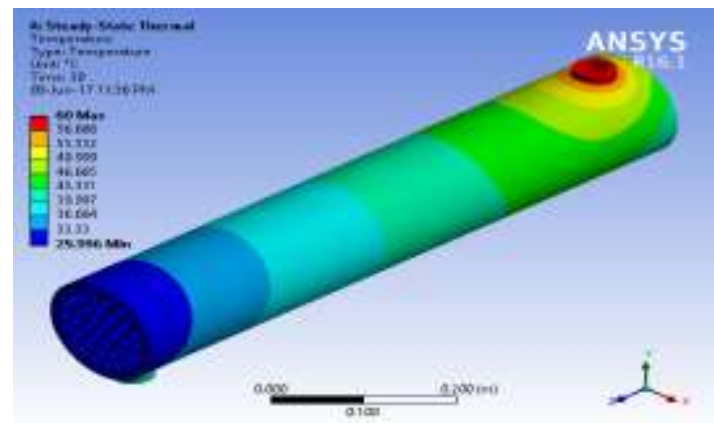

Figure 5.5: Temperature distribution in Brass

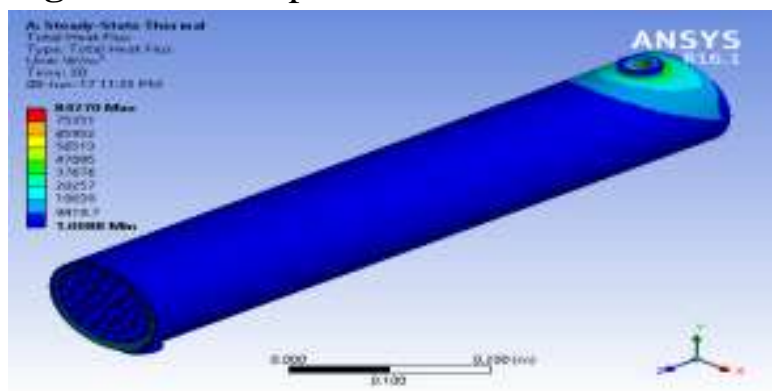

Figure 5.6: Heat distribution in Brass 


\section{IJMEIT// Vol.05 Issue 07//July//Page No: 1663-1670//ISSN-2348-196x}

Figure 5.5 and 5.6 shows the temperature variation and heat distribution in Brass in Parallel flow arrangement. The maximum and minimum values of the heat flux came out to be $1.399 \times 10^{5}$ and $0.010276 \mathrm{~W} / \mathrm{m}^{2}$.

\section{Brass in Counter flow}

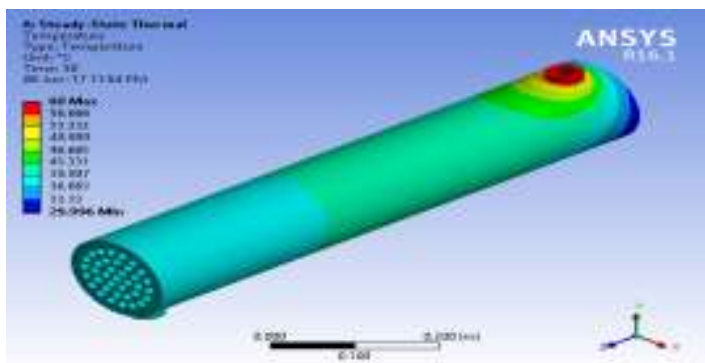

Figure 5.7: Temperature distribution in Brass

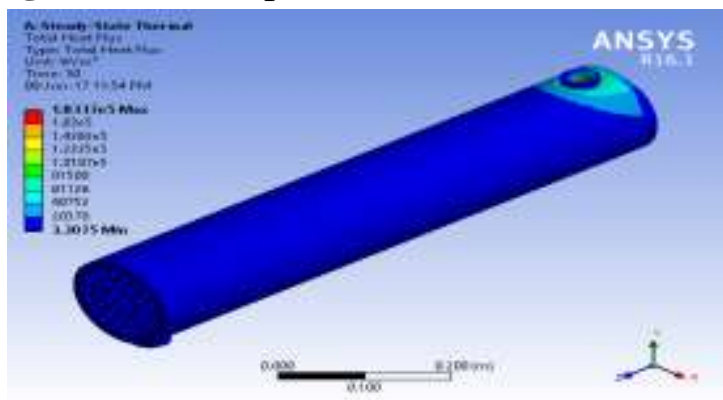

Figure 5.8: Heat distribution in Brass

Figure 5.7 and 5.8 shows the temperature variation and heat distribution in Brass in Counter flow arrangement. The maximum and minimum values of the heat flux came out to be $1.8337 \times 10^{5}$ and $0.019306 \mathrm{~W} / \mathrm{m}^{2}$.

\section{Copper in Parallel flow}

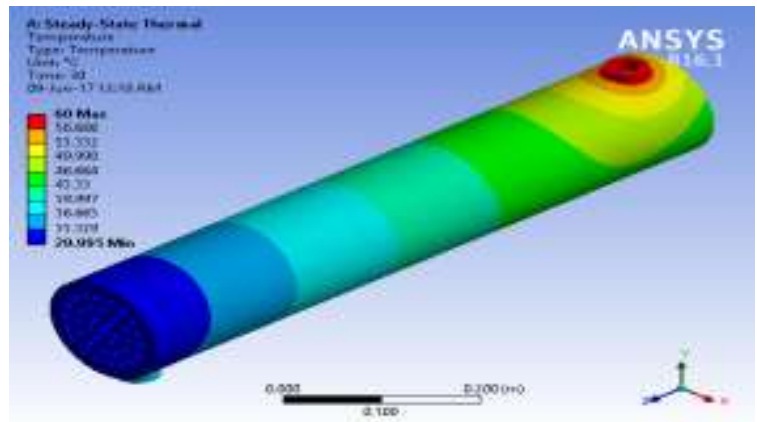

Figure 5.9: Temperature distribution in Copper

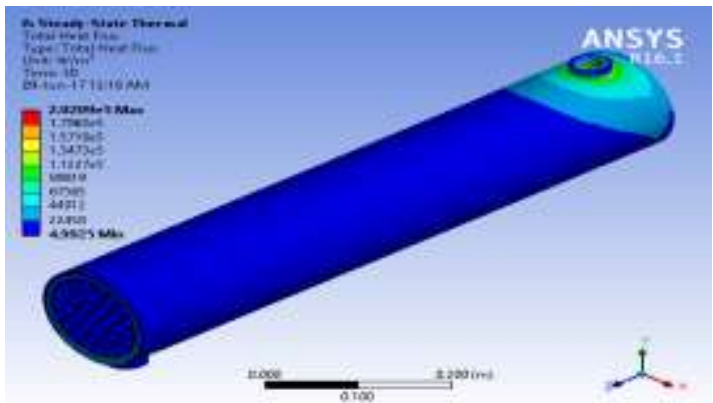

Figure 5.10: Heat distribution in Copper
Figure 5.9 and 5.10 shows the temperature variation and heat distribution in Copper in Parallel flow arrangement. The maximum and minimum values of the heat flux came out to be $3.1924 \times 10^{5}$ and $0.12294 \mathrm{~W} / \mathrm{m}^{2}$.

\section{Copper in Counter flow}

Figure 5.11 and 5.12 shows the temperature variation and heat distribution in Copper in Counter flow arrangement. The maximum and minimum values of the heat flux came out to be $6.6077 \times 10^{5}$ and $0.20041 \mathrm{~W} / \mathrm{m}^{2}$.

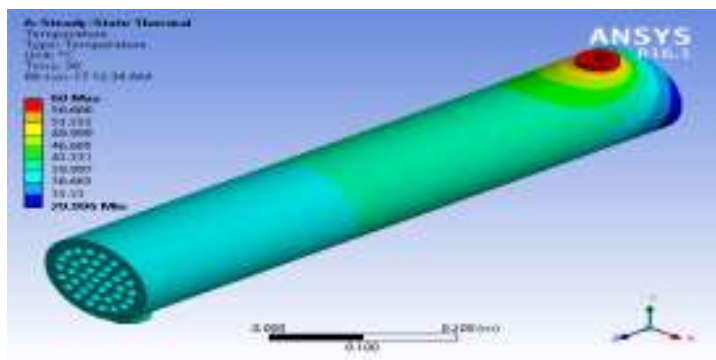

Figure 5.11: Temperature distribution in Copper

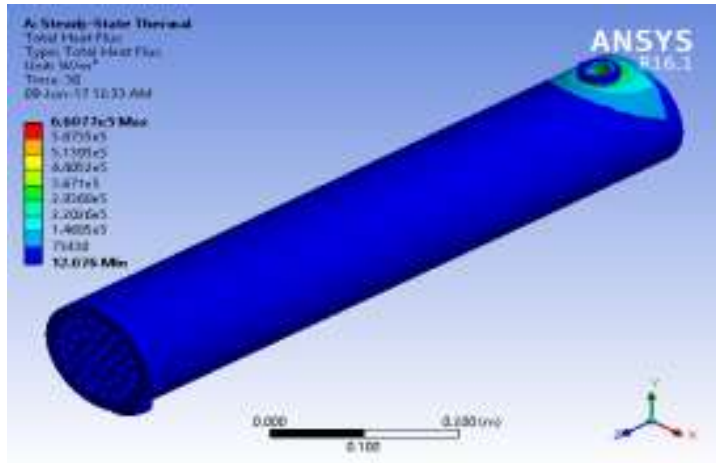

Figure 5.12: Heat distribution in Copper Steel 1008 in Parallel flow

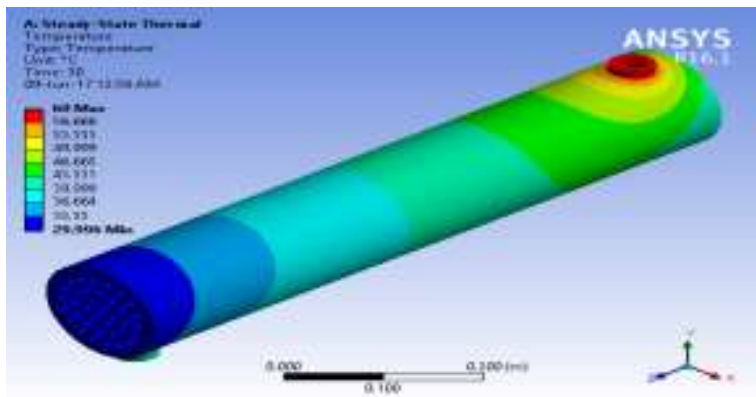

Figure 5.13: Temperature distribution in Steel 1008

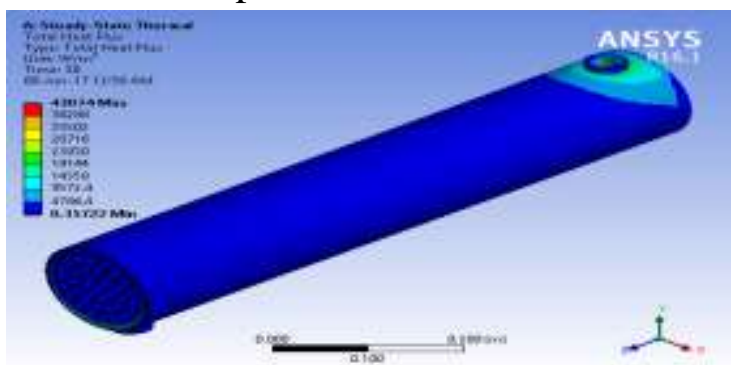

Figure 5.14: Heat distribution in Steel 1008 
Figure 5.13 and 5.14 shows the temperature variation and heat distribution in Steel 1008 in Parallel flow arrangement. The maximum and minimum values of the heat flux came out to be 71270 and $0.0073615 \mathrm{~W} / \mathrm{m}^{2}$

Steel in Counter flow

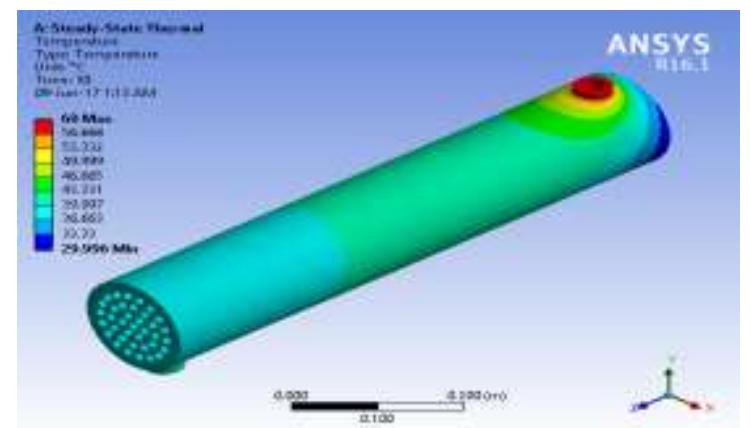

Figure 5.15: Temperature distribution in Steel 1008

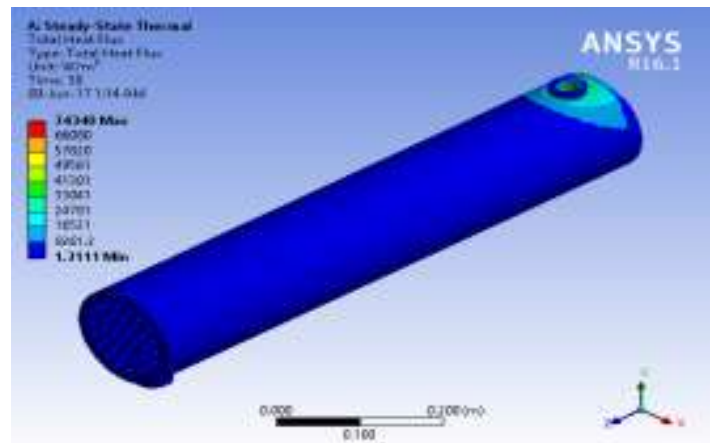

Figure 5.16: Heat distribution in Steel 1008

Figure 5.15 and 5.16 shows the temperature variation and heat distribution in Steel 1008 in Counter flow arrangement. The maximum and minimum values of the heat flux came out to be 74340 and $0.0027533 \mathrm{~W} / \mathrm{m}^{2}$.

\section{Maximum Heat Flux (W/m²)}

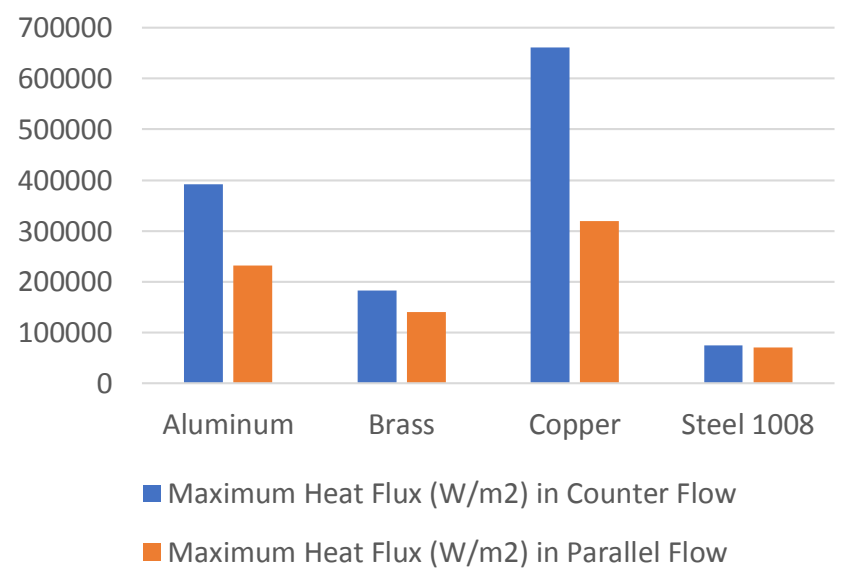

Figure 5.17: Bar chart showing the comparison between Maximum Heat Flux W/m²
Minimum Heat Flux $\left(\mathrm{W} / \mathrm{m}^{2}\right)$

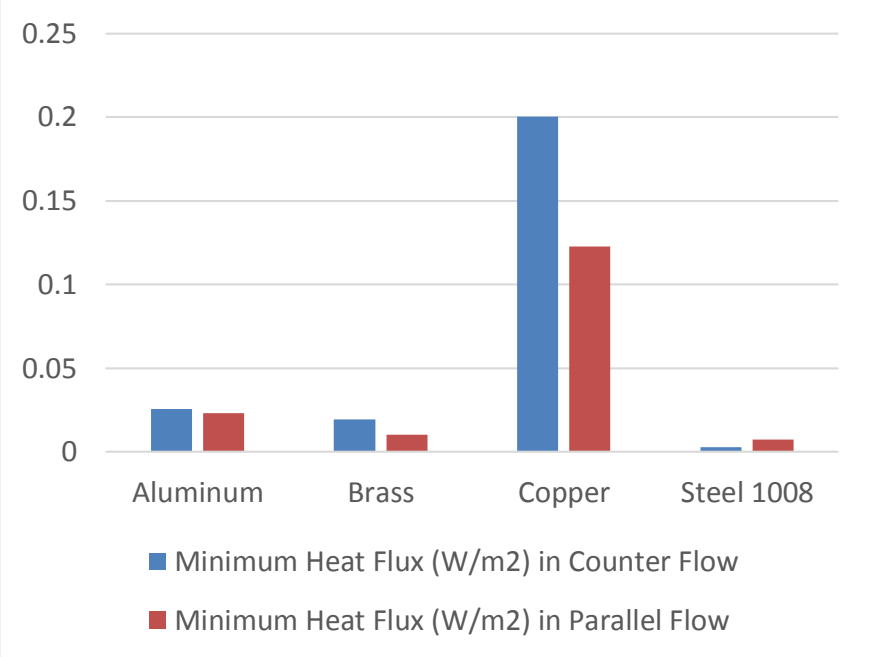

Figure 5.18: Bar chart showing the comparison between Maximum Heat Flux W/m²

\section{CONCLUSIONS}

After performing all the analysis work for shell \& tube heat exchangers the following observation had been done. From the study of the result as mentioned above, after performing the calculation the fluid water output temperatures for Aluminium, Brass, Copper and Steel 1008 are $37^{\circ} \mathrm{C}$ which is nearer to the value mentioned in output temperature of ANSYS. As we change the tube material to copper, Heat distribution increases. Analysis has been done by varying the tube materials and it is found that copper material gives the better heat transfer rates than the rest of the material used in this work.

Based on above study, a lot of factors affect the performance of the heat exchanger and the optimization obtained by the formulas depicts the cumulative effect of all the factors over the performance of the heat exchanger. It is observed that by changing the value of one variable by keeping the rest variable as constant we can obtain the different results. Based on that result we can optimize the design of the shell and tube type heat exchanger. So, while optimization it must be taken care that the advantage in one of the output parameter can affect the other parameters, which can lead to increase in initial or operating cost.

The results of the above study may be summarized as follows: 
Table 5.1: Comparison of heat flux of various materials

\begin{tabular}{|c|c|c|c|}
\hline Material & $\begin{array}{c}\text { Flow } \\
\text { Pattern }\end{array}$ & $\begin{array}{c}\text { Maximum } \\
\text { Heat Flux } \\
\left(\mathrm{W} / \mathrm{m}^{2}\right)\end{array}$ & $\begin{array}{c}\text { Minimum } \\
\text { Heat Flux } \\
\left(\mathrm{W} / \mathrm{m}^{2}\right)\end{array}$ \\
\hline Aluminium & Counter & $3.9234 \times 10^{5}$ & 0.025584 \\
\hline Aluminium & Parallel & $2.3227 \times 10^{5}$ & 0.023067 \\
\hline Brass & Counter & $1.8337 \times 10^{5}$ & 0.019306 \\
\hline Brass & Parallel & $1.399 \times 10^{5}$ & 0.010276 \\
\hline Copper & Counter & $6.6077 \times 10^{5}$ & 0.20041 \\
\hline Copper & Parallel & $3.1924 \times 10^{5}$ & 0.12294 \\
\hline Steel 1008 & Counter & 74340 & 0.0027533 \\
\hline Steel 1008 & Parallel & 71270 & 0.0073615 \\
\hline
\end{tabular}

After the thermal analysis of STHE it was found that:

Rate of heat transfer can be improved by varying the tube diameter, length and no of tubes.

By changing the pitch lay out rate of heat transfer can be improved.

By changing the temperature of tubes and medium rate of heat transfer can be improved.

By changing the materials of tubes heat transfer rate can be improved.

Higher the thermal conductivity of the tube metallurgy higher the heat transfer rate will be achieved

From this study, if we assign copper to the whole assembly then we shall get the best possible value of heat flux amongst the discussed materials.

\section{REFERENCES}

1. Ender Ozden, Ilker Tari, 2010, "Shell side CFD analysis of a small Shell \& Tube Heat exchanger", Energy Conversion and Management

2. Patel.P, Paul.A, 2012, "Thermal Analysis of Tubular Heat Exchanger by Using Ansys", International Journal of Engineering Research \& Technology (IJERT), Vol. 1 Issue 8, ISSN: 2278-0181

3. Bhatt.D., Javhar Priyanka.M, 2014, "Shell and Tube Heat Exchanger Performance Analysis", International Journal of Science and Research (IJSR), Volume 3, Issue 9, ISSN (Online): 23197064

4. Hetal Kotwal, D.S PATEL, 2013, "CFD Analysis of Shell and Tube Heat ExchangerA Review", International Journal of
Engineering Science and Innovative Technology (IJESIT), Volume 2, Issue 2, ISSN: 2319-5967

5. B.Jayachandriah, K. Rajasekhar, 2014, "Thermal Analysis of Tubular Heat Exchangers Using ANSYS", International Journal of Engineering Research, Volume No.3 Issue No: Special 1, pp: 21-25, ISSN:2319-6890)(online),2347-5013(print)

6. Triloki Nath Mishra, 2015, "Modelling and CFD Analysis of Tube in Tube Helical Coil Heat Exchanger", International Journal of Science and Research, Volume 4, Issue 8, ISSN (Online): 2319-7064

7. Vindhya Vasiny Prasad Dubey, Raj Rajat Verma, Piyush Shanker Verma \& A. K. Srivastava, 2014, "Steady State Thermal Analysis of Shell and Tube Type Heat Exchanger to Demonstrate the Heat Transfer Capabilities of Various Thermal Materials using Ansys", Global Journal of Researches in Engineering: A Mechanical and Mechanics Engineering, Volume 14 Issue 4 Version 1.0, ISSN:2249-4596

8. Gajanan P Nagre1, A. V. Gadekar, 2014, Jayachandriah.B, Rajasekhar.K, 2014, "Thermal Analysis of Tubular Heat Exchangers Using ANSYS", International Journal of Engineering Research-Volume No.3 Issue No:1, pp: 21-25, ISSN:23196890) 